\title{
ADJUVANT CHEMOTHERAPY IN THE TREATMENT OF CLINICALLY LOCALISED EWING'S SARCOMA
}

\author{
G. BACCI, M. CAMPANACCI, P. A. PAGANI
}

From Istituto Ortopedico Rizzoli, Bologna

The results are presented of thirty-seven patients with Ewing's sarcoma; ten were treated by a combination of operation, radiotherapy and cyclic chemotherapy, the remainder by radiotherapy and chemotherapy but without operation. The drugs, vincristine, cyclophosphamide and adriamycin were used in combination and were continued for two years. The follow-up ranged from twelve to sixty-two months.

The mortality rate and the incidence of metastases were both markedly lower than in a comparable previous series treated by radiotherapy alone, or by operation plus radiotherapy, but all without chemotherapy. The percentage of local recurrences and of metastases was much higher in the twenty-seven patients who had radiotherapy and adjuvant chemotherapy, than in the ten in whom operation was also performed. It is suggested that on the basis of these results (and on theoretical grounds) treatment should consist of radiotherapy combined with chemotherapy plus, whenever feasible, operative excision of the primary tumour.

In clinically localised Ewing's sarcoma, the results of merely local treatment of the primary tumour have been extremely poor. Falk and Alpert (1967) collected 987 such cases from the literature and found a cure rate after five years of 8 per cent. Since the survival rate of operation does not differ from that of irradiation, the latter is preferred by most authors (Jaffe 1958; Boyer, Brickner and Perry 1967; Phillips and Higinbotham 1967; Pratt 1972; Larson, Boquist and Bergdahl 1973; Lichtenstein 1973; Rosen et al. 1974; Pomeroy and Johnson 1975). This preference is reinforced by the fact that the response to radiation is rapid and complete, particularly since the advent of megavoltage radiation therapy.

In 1968 Hustu et al. suggested combining systemic chemotherapy with local radiotherapy, assuming that in most cases of apparently localised Ewing's sarcoma tumour cells were already disseminated, even in the absence of clinical or radiological manifestations. The first results of this adjuvant chemotherapy have been very encouraging (Phillips and Higinbotham 1967; Hustu et al. 1968; Freeman et al. 1972; Fernandez et al. 1974; Rosen et al. 1974; Bacci et al. 1975; Pomeroy and Johnson 1975; Sinks and Shan 1975; Jaffe et al. 1976). They show a significant lengthening of disease-free survival and provide real hope of an increase in cure rate. The infrequency of the Ewing's sarcoma, however, makes the number of treated cases too small for accurate statistical evaluation. Moreover, many of the recorded cases have only a short follow-up.

We therefore felt it would be of interest to report the results obtained at the Tumour Centre of our
Institute in thirty-seven consecutive cases of Ewing's sarcoma, in which local treatment of the primary tumour (radiotherapy or wide excision plus radiation) was combined with systemic chemotherapy using vincristine, cyclophosphamide and adriamycin. This adjuvant chemotherapy was continued for two years.

\section{MATERIAL AND METHODS}

Thirty-seven consecutive cases of Ewing's sarcoma were treated between January 1972 and June 1976. None had signs of pulmonary or bony metastases on standard radiographs when treatment began. Scintigraphy was not carried out. Age, sex, initial localisation, course and treatment of the primary tumour are reported in Table $I$.

Diagnosis was based on the histological study of representative sections, using PAS diastase stain for glycogen, and silver stain for reticulum fibres. In some cases (particularly small children) the urinary catecholamine metabolites were investigated to rule out the possibility of metastatic neuroblastoma. A few others had features suggesting a histiocytic lymphoma; if there was genuine diagnostic doubt such cases were excluded from the series and we feel confident that, in the thirty-seven cases reported here, the diagnosis of Ewing's sarcoma was firmly established.

Operation, whether biopsy or excision, was followed immediately by chemotherapy (vincristine $1 \mathrm{mg} / \mathrm{m}^{2}$ and cyclophosphamide 500 $\mathrm{mg} / \mathrm{m}^{2}$ four hours after operation, and cyclophosphamide $500 \mathrm{mg} / \mathrm{m}^{2}$ next day).

In ten patients the primary tumour was treated surgically: radical resection in four, scapulectomy in three and subtotal excision in three cases. In all ten the operation was followed by local radiotherapy.

The primary tumour was treated by radiotherapy alone in twenty-seven cases. Radiation was started approximately ten days after the biopsy using caesium-137. The dose, number of fractions, and total time of treatment varied according to the site and volume of the tumour and the age of the patient (Table I). In the majority of the cases the teletherapy was delivered over a period of five to seven weeks with a total dose of $\mathbf{4 5 0 0}$ to 5000 rads. The ports were extended to include the entire involved bone and surrounding soft tissues. The concomit- 


\begin{tabular}{|c|c|c|c|c|c|c|c|c|c|c|c|c|c|c|c|}
\hline$\frac{8}{8}$ & 11 & 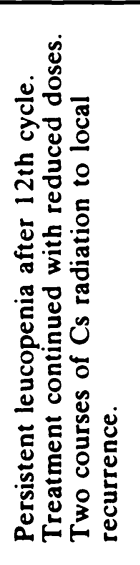 & 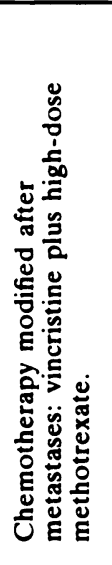 & 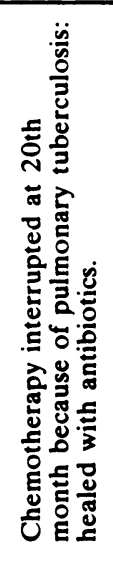 & 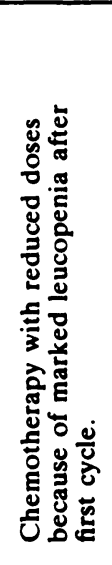 & 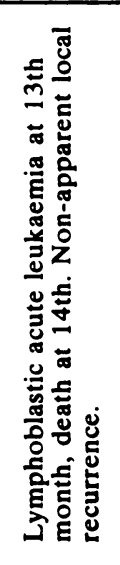 & 1 & 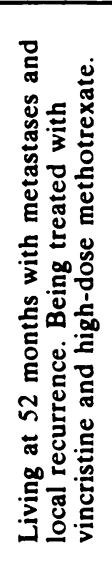 & 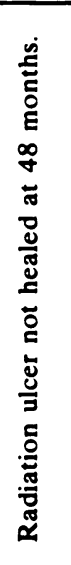 & 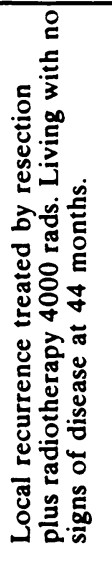 & 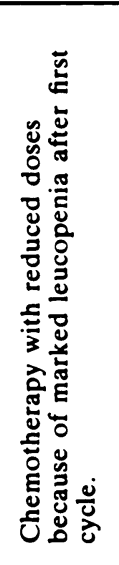 & 1 & 11 & 11 & 1 \\
\hline 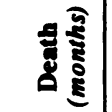 & 11 & $\stackrel{\infty}{m}$ & $\stackrel{\sim}{N}$ & 1 & 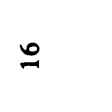 & \pm & 1 & 1 & 1 & 1 & 1 & 11 & 11 & 11 & 1 \\
\hline 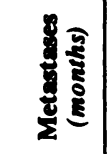 & 11 & 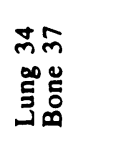 & 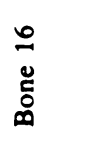 & 1 & 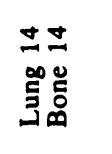 & 1 & 1 & 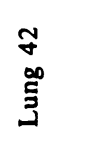 & 1 & 1 & 1 & 11 & 1 & 1 & 1 \\
\hline 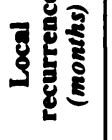 & 11 & $=$ & 1 & 1 & $=$ & 1 & 1 & $\infty$ & 1 & p & 1 & 11 & 11 & 1 & 1 \\
\hline 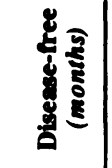 & $\widetilde{1}$ & 1 & 8 & 8 & 1 & 1 & i̊ & 1 & $\stackrel{\infty}{\rightarrow}$ & 1 & $\mathcal{F}$ & $q$ i & $\hat{m}$ & $\stackrel{m}{m}$ & 요 \\
\hline 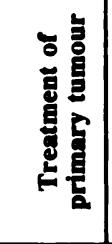 & 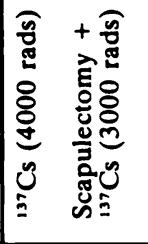 & 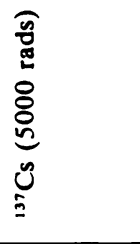 & 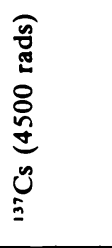 & 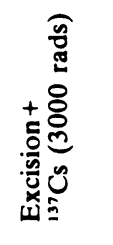 & 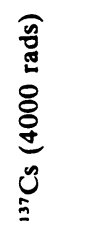 & 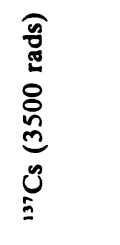 & 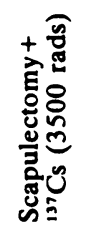 & 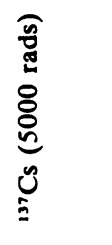 & 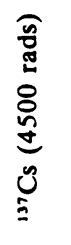 & 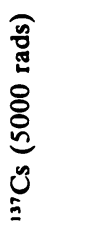 & 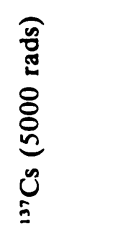 & 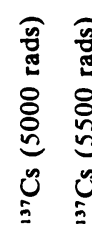 & 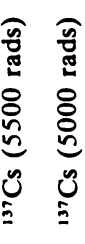 & 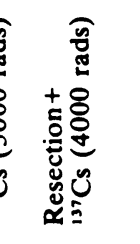 & 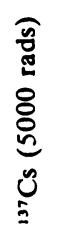 \\
\hline 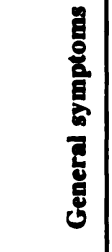 & 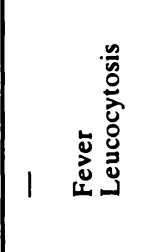 & 1 & 1 & 1 & 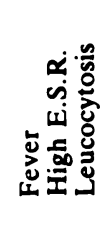 & 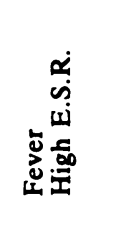 & 离 & 1 & 1 & 1 & 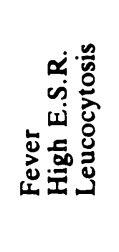 & 1 & 离 & 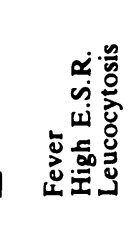 & 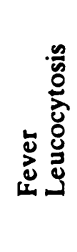 \\
\hline 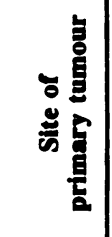 & 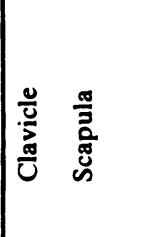 & $\stackrel{E}{\Xi}$ & $\stackrel{\vec{\alpha}}{\alpha}$ & $\stackrel{\underline{g}}{\underline{\Xi}}$ & 兰 & 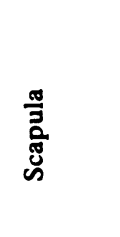 & 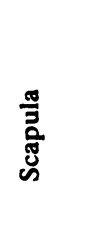 & : & : & $\begin{array}{l}\frac{\pi}{3} \\
\text { हूँ } \\
\text { ڤ్ }\end{array}$ & $\frac{\pi}{5}$ & $\stackrel{\mathscr{3}}{\mathscr{a}}$ & 尊 & 巳 & 氙 \\
\hline$y$ & 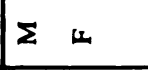 & $L$ & $\Sigma$ & $\Sigma$ & $\omega$ & $\omega$ & $\omega$ & L & $\Sigma$ & $\omega$ & $\Sigma$ & $\omega$ & $\Sigma \Sigma$ & 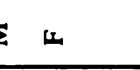 & $\Sigma$ \\
\hline \% & $\approx \approx$ & $\stackrel{0}{0}$ & $\simeq$ & ฉ & $\stackrel{\infty}{\sim}$ & 운 & $=$ & $\approx$ & $=$ & $=$ & $=$ & $\tilde{m} \stackrel{\infty}{=}$ & $\stackrel{=}{=}$ & $=n$ & $=$ \\
\hline 密案 & $\because \quad \sim$ & in & $\dot{\theta}$ & $n$ & $\dot{0}$ & $\ddot{r}$ & $\infty$ & $a$ & $\dot{\vdots}$ & $=$ & $\simeq$ & $2 \pm$ & $\pm n$ & $2 \div$ & $=$ \\
\hline
\end{tabular}




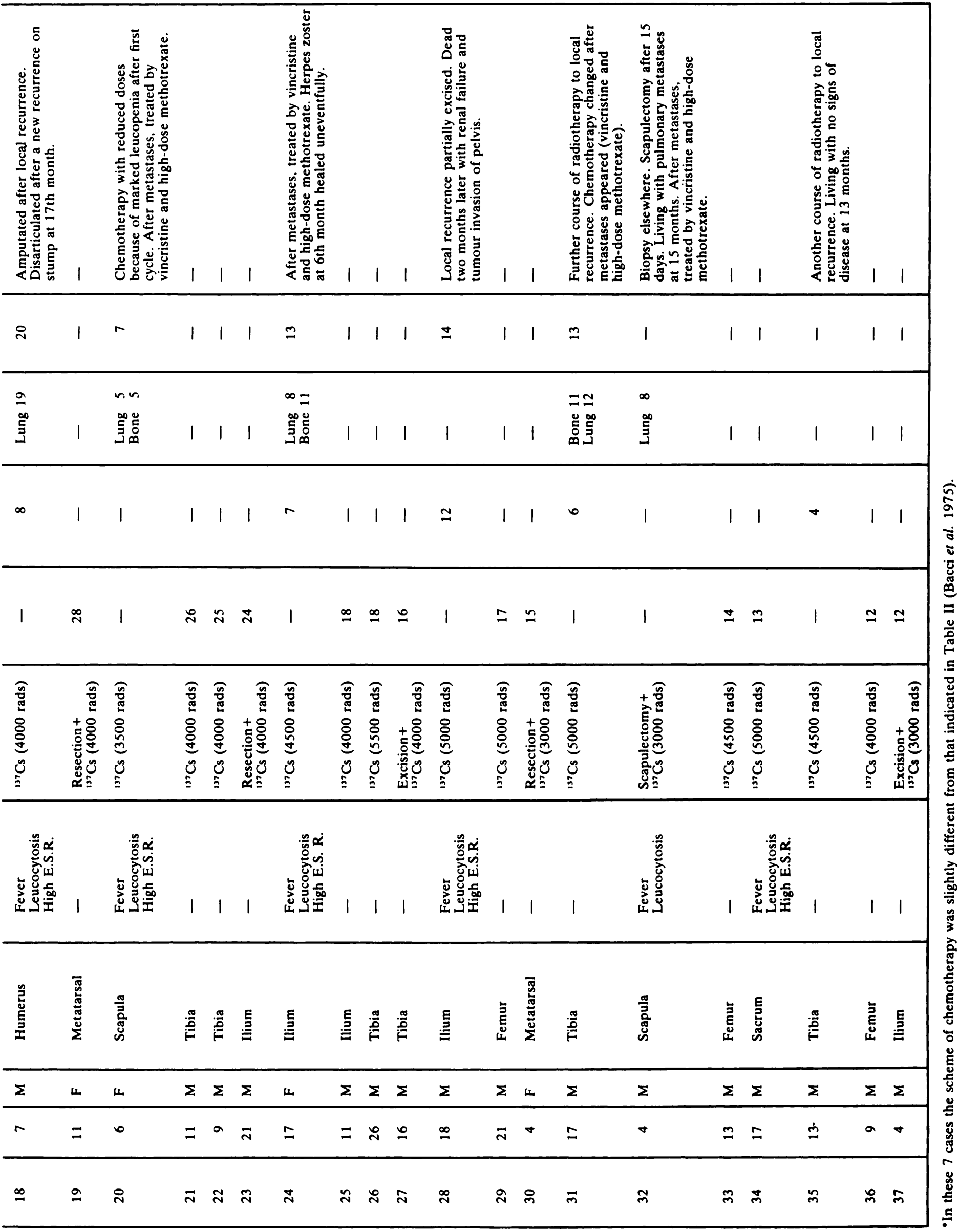


ant administration of chemotherapy decreases the tolerance of normal tissues to radiation (Rosen et al. 1974; Tefft et al. 1976); consequently the total dose of irradiation was lower than in other reported series (Pratt 1972; Suit et al. 1973; Rosen et al. 1974). Above 4000 rads, however, there seems to be no definite correlation between the dose of radiation and the local control of the tumour (Suit et al. 1973; Fernandez et al. 1974; Macintosh, Price and Jeffree 1975). With tumours in the pubis and lower ilium, where irradiation would necessarily involve the bladder, cyclophosphamide (which is a powerful bladder toxin) was omitted during the period of irradiation (Jayalakshmamma and Pinkel 1976).

Adjuvant chemotherapy was given as shown in Table II and was continued for two years. In eight cases (Table I) it was started at the end of the radiation course, in the remaining twenty-nine it was concurrent with radiotherapy. The drugs used were those which had proved most effective in treating metastases from Ewing's sarcoma: the tumour, and type of local treatment (Tables IV and V). Even as far as the radiotherapy is concerned, there were no significant differences between the two series.

\section{RESULTS}

Operation plus radiotherapy plus chemotherapy. None of the ten patients who had their primary tumour operated upon had any local recurrence, even when the excision was incomplete. One developed pulmonary metastases eight months after operation; the remaining nine patients had no signs of disease at follow-up varying from twelve to sixty-two months (average thirty-four months) after operation.

Table II. Adjuvant chemotherapy scheme

\begin{tabular}{|c|l|l|c|l|}
\hline & & \multicolumn{1}{|c|}{ Drug } & $\begin{array}{c}\text { Dose in milligrams per } \\
\text { square metre }\end{array}$ & \multicolumn{1}{c|}{ Notes } \\
\hline $\begin{array}{c}\text { Cycle } \\
\text { A }\end{array}$ & Day 1 & adriamycin & 50 & $\begin{array}{l}10 \text { consecutive cycles } \\
\text { at 21-day intervals }\end{array}$ \\
& Day 2 & $\begin{array}{l}\text { vincristine } \\
\text { cyclophosphamide }\end{array}$ & 300 & 1.5 \\
cyclophosphamide & 300 & 1 & $\begin{array}{l}\text { 32 consecutive cycles at } \\
\text { 14-day intervals, starting } \\
\text { Day 4 days after the end of } \\
\text { cycle A }\end{array}$ \\
\hline $\begin{array}{c}\text { Cycle } \\
\text { B }\end{array}$ & $\begin{array}{l}\text { Both drugs } \\
\text { on }\end{array}$ & $\begin{array}{l}\text { vincristine } \\
\text { plus } \\
\text { cyclophosphamide }\end{array}$ & 800 & \begin{tabular}{c} 
same day \\
\hline
\end{tabular}
\end{tabular}

vincristine (Goepfert, Rochlin and Smart 1967; Sutow 1968; Sutow et al. 1971); cyclophosphamide (Sutow and Sullivan 1962; Goepfert et al. 1967; Samuels and Howe 1967; Sutow et al. 1971); and adriamycin (Oldham and Pomeroy 1972; O'Bryan et al. 1973; Gottlieb 1974). Combinations of drugs were used which, both experimentally (Goldman and Fyfe 1973) and clinically (Pouillart et al. 1972, 1974), enhanced each other's cytotoxic effect, without having too high a total toxicity. The drugs were administered in such a sequence as to obtain recruitement and synchronisation of the neoplastic cells (Mathé, Schneider and Schwarzenberg 1970; Pouillart et al. 1972; Mathé and Kernis 1975). Administration was intermittent in order to minimise the effects of immunodepression and myelodepression (Pouillart et al. 1972; Mathé and Kernis 1975).

The interval between the cycles of treatment should be long enough for haematological and immunological recovery. The cycle was not given when the white cell count was less than 3500 or the platelets less than $100000 / \mathrm{mm}^{3}$. Intermittent treatment also has the advantage of causing a constant and reasonably predictable myelodepression in any given patient (Pouillart et al. 1972; Mathe and Kernis 1975). This last point is of great importance, because after the first two cycles in hospital under strict haematological control, treatment continues as an outpatient, and a blood and platelet count is taken the day before the beginning of each cycle.

Blood and platelet counts were done the day before the beginning of each cycle and an electrocardiogram at the end of each cycle that included adriamycin. A stricter haematological control was employed during the first two cycles which were administered in hospital in association with radiotherapy. Every three months radiographs of the primary skeletal lesion and of the chest were taken; radiographic survey of other bones was performed only when clinically indicated.

To evaluate the effect of the adjuvant chemotherapy a comparison was made with a series of consecutive cases of Ewing's sarcoma previously treated in our Institute (1960 to 1970) by operation, by radiotherapy, of by both, but without chemotherapy. These cases matched the present series as regards age, localisation of
Radiotherapy plus chemotherapy. Initially, all twentyseven patients had apparently complete regression of the tumour. Fifteen were in good health with no signs of disease twelve to sixty-two months (average twentynine months) after the beginning of treatment. Distant metastases with no signs of local recurrence were observed in two patients after five and sixteen months respectively; they were noted in the skeleton and lungs in one patient, in the skeleton only in the other, this second patient having signs of cerebral involvement associated with adjacent bone metastases in the skull. These patients died at seven and twenty-four months respectively after the beginning of treatment. We cannot rule out the possibility that, had they lived longer, a local recurrence would have appeared.

Local recurrence occurred in nine instances, at four to forty-eight months (average fifteen months) after the beginning of treatment. In six of these it was associated with metastases. In five cases these appeared at one to twenty-one months after the local recurrence, in one metastases developed six months before the appearance of the local recurrence. Five of these patients died between thirteen and thirty-eight months after the beginning of treatment; one is still living, with multiple metastases, fifty-one months after the beginning of treatment. Of the three patients who had local recurrence without apparent metastases, one died of complications due to the local recurrence. Of the remaining two one had the local recurrence treated by 
operation, the other by radiation; both were living with no signs of disease at thirteen and forty-four months respectively after the beginning of the initial treatment. One patient died with an acute lymphoblastic leukaemia which appeared thirteen months after the beginning of treatment; there were no signs of local recurrence.

In contrast to other reports (Marsa and Johnson 1971; Mehta and Hendrickson 1974) no example of cerebral or meningeal involvement was encountered.

\section{TOXICITY AND COMPLICATIONS}

On the whole the chemotherapy was well tolerated. The main side-effects are reported in Table III. In addition, there were local complications at the radiation site: transitory oedema and induration of the irradiated limb in three cases; inflammatory reaction at the site of biopsy in three cases; one radiation ulcer; and one fracture of the tibia at the site of biopsy.

Table III. Toxicity and complications

\begin{tabular}{|l|c|}
\hline \multicolumn{1}{|c|}{ Complications } & Number of patients \\
\hline Leucopenia $\left(<1000 / \mathrm{mm}^{3}\right)$ & 3 \\
Alopecia & 34 \\
Infections & 1 miliary pulmonary \\
& 1 herpes zoster \\
Severe nausea and vomiting & 17 \\
Neurotoxicity & 15 \\
Cardiac toxicity-clinical & 0 \\
& 1 \\
\hline
\end{tabular}

A constant but transitory leucopenia was seen with maximum reduction at the tenth to the fourteenth day after the beginning of cycle $A$. The level usually remained between 1000 and 1500 per cubic millimetre. Only in three cases, after the first two cycles administered during radiotherapy, was leucopenia more pronounced (500 to 800 per cubic millimetre); in these three treatment was continued with reduced doses. Except in two cases, complete restoration to normal was seen within twenty days from the beginning of cycle A and within fourteen days from the beginning of cycle B. This restoration occurred even after repeated treatment cycles.

Twenty-two of our patients have already finished treatment. In none was there significant reduction of platelets. Two patients had infective complications: one developed miliary pulmonary tuberculosis which healed with antibiotics; the other developed herpes zoster, which also healed. There was constant but reversible alopecia, and moderate to severe nausea and vomiting in two-thirds of the patients. It usually began in the first twelve hours after beginning chemotherapy and persisted for twelve to twenty-four hours. After repeated treatment cycles, there was usually an attenuation of the gastric disturbances.

All patients developed depression or absence of patellar and calcaneal reflexes typical of vincristine neurotoxicity. Notable but transitory numbness was observed in about one third of the patients. Only in one case, at the end of the tenth cycle with adriamycin, did the electrocardiogram show transitory changes of the $\mathrm{S}-\mathrm{T}$ and $\mathrm{T}$ waves.

\section{DISCUSSION}

The number of patients was too small to enable a differential prognosis to be made according to site, volume of the tumour and clinical signs. It should be noted, however, that twenty-five patients in the present series could be considered to have a high risk of early metastases, either because of the site of the primary tumour (scapula, ilium, ribs, sacrum) or because of an associated fever, greatly raised sedimentation rate and marked leucocytosis (Falk and Alpert 1967; Lichtenstein 1973; Pomeroy and Johnson 1975).

Our study confirms that, in Ewing's sarcoma, adjuvant chemotherapy is capable of limiting or destroying the micrometastases. The limited number of treated patients with as yet a comparatively short

Table IV. Comparison of disease-free follow-up in patients treated with or without chemotherapy

\begin{tabular}{|c|c|c|c|c|c|c|c|c|}
\hline \multirow[b]{2}{*}{$\begin{array}{l}\text { Number } \\
\text { of cases }\end{array}$} & \multirow[b]{2}{*}{$\begin{array}{l}\text { Treatment of } \\
\text { primary tumour }\end{array}$} & \multicolumn{5}{|c|}{ Patients with no signs of disease } & \multirow[b]{2}{*}{ Metastases } & \multirow[b]{2}{*}{$\begin{array}{l}\text { Local } \\
\text { recurrence }\end{array}$} \\
\hline & & $\begin{array}{l}\text { After } \\
1 \text { year }\end{array}$ & $\begin{array}{l}\text { After } \\
2 \text { years }\end{array}$ & $\begin{array}{c}\text { After } \\
3 \text { years }\end{array}$ & $\begin{array}{l}\text { After } \\
4 \text { years }\end{array}$ & $\begin{array}{l}\text { After } \\
5 \text { years }\end{array}$ & & \\
\hline $\begin{array}{l}14 \\
26\end{array}$ & $\begin{array}{l}1960-1970 \text { series } \\
\text { Operation and } \\
\text { radiotherapy } \\
\text { Radiotherapy only }\end{array}$ & $\begin{array}{c}10 \text { of } 40 \\
(25 \%)\end{array}$ & $\begin{array}{l}3 \text { of } 40 \\
(7 \%)\end{array}$ & $\begin{array}{c}2 \text { of } 40 \\
(5 \%)\end{array}$ & $\begin{array}{c}2 \text { of } 40 \\
(5 \%)\end{array}$ & $\begin{array}{c}1 \text { of } 40 \\
(2 \%)\end{array}$ & $\begin{array}{l}38 \text { of } 40 \\
\text { After } 8 \text { months } \\
\text { (range } 3-49 \text { ) }\end{array}$ & $\begin{array}{l}5 \text { of } 40 \\
\text { After } 8 \text { months } \\
\text { (range } 6-14)\end{array}$ \\
\hline $\begin{array}{l}10 \\
27\end{array}$ & $\begin{array}{l}1972-1976 \text { series } \\
\text { Operation, radiotherapy } \\
\text { and chemotherapy } \\
\text { Radiotherapy and } \\
\text { chemotherapy }\end{array}$ & $\begin{array}{c}25 \text { of } 37 \\
(62 \%)\end{array}$ & $\begin{array}{c}15 \text { of } 24 \\
(62 \%)\end{array}$ & $\begin{array}{l}9 \text { of } 15 \\
(60 \%)\end{array}$ & $\begin{array}{l}5 \text { of } 10 \\
(50 \%)\end{array}$ & $\begin{array}{l}3 \text { of } 6 \\
(50 \%)\end{array}$ & $\begin{array}{l}9 \text { of } 37 \\
\text { After } 19 \text { months } \\
\text { (range } 5-42 \text { ) }\end{array}$ & $\begin{array}{l}9 \text { of } 37 \\
\text { After } 15 \text { months } \\
\text { (range } 4-48 \text { ) }\end{array}$ \\
\hline
\end{tabular}


Table V. Comparison of survival time in patients treated with and without chemotherapy

\begin{tabular}{|c|c|c|c|c|c|c|c|}
\hline \multirow[b]{2}{*}{$\begin{array}{c}\text { Number of } \\
\text { cases }\end{array}$} & \multirow[b]{2}{*}{$\begin{array}{l}\text { Treatment of } \\
\text { primary tumour }\end{array}$} & \multicolumn{5}{|c|}{ Survivors } & \multirow[b]{2}{*}{$\begin{array}{l}\text { Survival time of } \\
\text { fatal cases }\end{array}$} \\
\hline & & $\begin{array}{l}\text { After } \\
1 \text { year }\end{array}$ & $\begin{array}{l}\text { After } \\
2 \text { years }\end{array}$ & $\begin{array}{l}\text { After } \\
3 \text { years }\end{array}$ & $\begin{array}{c}\text { After } \\
4 \text { years }\end{array}$ & $\begin{array}{l}\text { After } \\
5 \text { years }\end{array}$ & \\
\hline $\begin{array}{l}14 \\
26\end{array}$ & $\begin{array}{l}1960-1970 \text { series } \\
\text { Operation and } \\
\text { radiotherapy } \\
\text { Radiotherapy alone }\end{array}$ & $\begin{array}{l}18 \text { of } 40 \\
(45 \%)\end{array}$ & $\begin{array}{l}7 \text { of } 40 \\
(17 \%)\end{array}$ & $\begin{array}{l}4 \text { of } 40 \\
(10 \%)\end{array}$ & $\begin{array}{c}3 \text { of } 40 \\
(7 \%)\end{array}$ & $\begin{array}{l}2 \text { of } 40 \\
(5 \%)\end{array}$ & $\begin{array}{l}38 \text { fatal cases } \\
\text { Average } 10 \text { months survival } \\
\text { (range } 5-50 \text { ) }\end{array}$ \\
\hline $\begin{array}{l}10 \\
27\end{array}$ & $\begin{array}{l}1972-1976 \text { series } \\
\text { Operation, radiotherapy } \\
\text { and chemotherapy } \\
\text { Radiotherapy and } \\
\text { chemotherapy }\end{array}$ & $\begin{array}{c}36 \text { of } 37 \\
(98 \%)\end{array}$ & $\begin{array}{l}19 \text { of } 24 \\
(80 \%)\end{array}$ & $\begin{array}{l}12 \text { of } 15 \\
(80 \%)\end{array}$ & $\begin{array}{l}6 \text { of } 10 \\
(60 \%)\end{array}$ & $\begin{array}{l}3 \text { of } 6 \\
(50 \%)\end{array}$ & $\begin{array}{l}9 \text { fatal cases } \\
\text { Average } 17 \text { months survival } \\
\text { (range } 7-51 \text { ) }\end{array}$ \\
\hline
\end{tabular}

Table VI. Local recurrence in patients treated by radiotherapy to primary site (reports in the literature)

\begin{tabular}{|c|c|c|c|c|c|}
\hline Author & $\begin{array}{l}\text { Number of } \\
\text { patients }\end{array}$ & $\begin{array}{l}\text { Local r } \\
\text { Numbe }\end{array}$ & $\begin{array}{l}\text { rences } \\
\text { r cent }\end{array}$ & $\begin{array}{l}\text { Range } \\
\text { (months) }\end{array}$ & $\begin{array}{l}\text { Mean } \\
\text { (months) }\end{array}$ \\
\hline $\begin{array}{l}\text { No chemotherapy } \\
\text { Boyer, Brickner and Perry } \\
\text { (1967) }\end{array}$ & 6 & 2 & 33 & $5-17$ & 11 \\
\hline $\begin{array}{l}\text { Marsden and Steward } \\
\text { (1968) }\end{array}$ & 22 & 12 & 54 & $?$ & $?$ \\
\hline $\begin{array}{l}\text { Phillips and Sheline } \\
\text { (1969) }\end{array}$ & 20 & 5 & 25 & $?-14$ & $?$ \\
\hline $\begin{array}{l}\text { Jenkin, Rider and Sonley } \\
\text { (1970) }\end{array}$ & 12 & 6 & 50 & $?$ & $?$ \\
\hline $\begin{array}{l}\text { Freeman et al. } \\
\text { (1972) }\end{array}$ & 8 & 4 & 50 & $3-8$ & 5 \\
\hline $\begin{array}{l}\text { Rosen et al. } \\
(1974)\end{array}$ & 16 & 7 & 43 & $6-26$ & 11 \\
\hline $\begin{array}{l}\text { Macintosh, Price and Jeffree } \\
\text { (1975) }\end{array}$ & 27 & 14 & 52 & $3-23$ & $?$ \\
\hline $\begin{array}{l}\text { With chemotherapy } \\
\text { Freeman et al. } \\
\text { (1972) }\end{array}$ & 4 & 3 & 75 & $3-15$ & 7 \\
\hline $\begin{array}{l}\text { Hustu et al. } \\
(1972)\end{array}$ & 9 & 1 & 11 & 10 & 10 \\
\hline $\begin{array}{l}\text { Suit et al. } \\
\text { (1973) }\end{array}$ & 11 & 1 & 9 & $?$ & $?$ \\
\hline $\begin{array}{l}\text { Rosen et al. } \\
(1974)\end{array}$ & 10 & 0 & & - & - \\
\hline $\begin{array}{l}\text { Pomeroy and Johnson } \\
(1975)\end{array}$ & 44 & 3 & 6 & $?$ & $?$ \\
\hline $\begin{array}{l}\text { Jaffe et al. } \\
(1976)\end{array}$ & 8 & 2 & 25 & $?$ & $?$ \\
\hline
\end{tabular}

"Only those patients followed up for at least one year have been included.

follow-up does not permit definitive conclusions. There is no doubt, however, that adjuvant chemotherapy increases the period of freedom from disease.

A comparison between the results of treatment with and without adjuvant chemotherapy (Table IV), shows a significant difference in the incidence of metastases at follow-up. Furthermore the metastases developed later in the patients treated by adjuvant chemotherapy (average nineteen months in comparison with eight months). The length of survival of fatal cases also was longer in the chemotherapy group (average seventeen months against ten months) (Table V). 
In our experience, adjuvant chemotherapy did not reduce the high incidence of local recurrence after radiotherapy that has been reported by several authors (Table VI) and appears to be diminished by increasing doses of radiation over 4000 to 4500 rads (Suit et al. 1973; Fernandez et al. 1974; Macintosh et al. 1975). It was hoped that adjuvant chemotherapy would reduce the risk of local recurrences, which usually appear comparatively late in the disease and are almost invariably associated with the appearance of distant metastases (Chabora et al. 1976). The first reported results seemed to suggest a lower local recurrence rate (Table VI), though in most cases the follow-up was too short. Our experience, on the contrary, shows a higher incidence in the group treated by adjuvant chemotherapy (nine local recurrences) in comparison with the control group (five local recurrences). This finding could be due to the fact that a high percentage of the patients in the control group died six to eight months after beginning radiation treatment. Local recurrences earlier than this are unusual, so that their figures could give a falsely low impression. In other words, adjuvant chemotherapy, by protracting the course of the disease, might give time for local recurrences to appear.

Local recurrence, as already reported (Suit et al. 1973; Fernandez et al. 1974), always develops at the site of the primary tumour despite the fact that this site received the maximum dose of radiation. Local recurrence is never seen on the borders of the primary tumour or in the surrounding areas, which received minor doses of radiation. This suggests that the peripheral (and radiologically undetectable) areas of Ewing's sarcoma are destroyed by radiation doses of 4000 to 4500 rads, while the central core of the tumour is not destroyed, even with doses as high as 7000 rads and over. It can be assumed that, as with other neoplasms, in Ewing's sarcoma the central part of the tumour, with its poor blood supply and necrotic areas, contains hypoxic and therefore radioresistant cells. The peripheral areas of the tumour and the micronodes in the medullary spaces, on the contrary, have a better blood supply and are therefore more radioresponsive. Consequently it seems unlikely that adjuvant chemotherapy could reduce the incidence of local recurrences. Chemotherapeutic agents are in fact unlikely to reach the central, poorly vascularised, areas of the tumour. Even if they did so in a sufficient concentration, their action would probably be minimal on cells which, being hypoxic, are most likely to be mitotically quiescient and therefore resistant to cytotoxic drugs.

This differentiated cytotoxic effect of chemotherapeutic agents on the primary tumour and its micrometastases has been well demonstrated in a number of clinical and animal studies (Schabel 1975; Burchenal 1976) and our study confirms it.

The presence of live tumour cells inside an incompletely controlled primary tumour places the patient at an extreme risk of metastases, which may appear once chemotherapy has been completed. So the question arises whether metastases in Ewing's sarcoma develop from undetected micrometastases already present when treatment commenced, or whether they originate later from a tumour which the local therapy has been unable to control completely. This second possibility appears more likely; thus, of our ten patients whose primary tumours were treated surgically (and were therefore more easily controlled by subsequent radiation), only one developed metastases whereas eight of the twenty-seven patients who had radiotherapy alone developed them.

For these reasons we suggest that the treatment of Ewing's sarcoma should include operation as well as radiotherapy and adjuvant chemotherapy. This conclusion is in agreement with the findings of the Mayo Clinic's orthopaedic oncologists (Pritchard 1978). Operation may consist of amputation, especially for large tumours below the knee; in other cases it merely consists of radical or subtotal excision. The object of these operations is to remove the core of the tumour which is the more radioresistant and chemoresistant portion.

\section{REFERENCES}

Bacci, G., Figus, E., Cagnano, R., Pagani, P. A., and Orlandi, G. (1975) L'associazione terapia radiante locale-chemioterapia sistemica nel trattamento del sarcoma di Ewing clinicamente localizzato. Minerva Medica, 66, 1263-1273.

Boyer, C. W. Jun., Brickner, T. J. Jun., and Perry, R. H. (1967) Ewing's sarcoma. Case against surgety. Cancer, 20, $1602-1606$.

Burchenal, J. H. (1976) Adjuvant therapy-Theory, practice and potential. Cancer, 37, 46-57.

Chabora, B. McC., Rosen, G., Cham, W., D'Angio, G. J., and Teft, M. (1976) Radiotherapy of Ewing's sarcoma: local control with and without intensive chemotherapy. Radiology, 120, 667-671.

Falk, S., and Alpert, M. (1967) Five-year survival of patients with Ewing's sarcoma. Surgery, Gynecology and Obstetrics, 124, $319-324$.

Fernandez, C. H., Lindberg, R. D., Sutow, W., and Samuels, M. L. (1974) Localized Ewing's sarcoma-Treatment and results. Cancer, 34, $143-148$

Freeman, A. I., Sachatello, C., Gaeta, J., Shah, N. K., Wang, J. J., and Sinks, L. F. (1972) An analysis of Ewing's tumor in children at Roswell Park Memorial Institute. Cancer, 29, 1563-1569.

Goepfert, H., Rochlin, D. B., and Smart, C. R. (1967) Palliative treatment of Ewing's sarcoma. American Journal of Surgery, 113, 246-250.

Goldman, I. D., and Fyfe, M. J. (1973) Free intracellular methotrexate (MTX) is required for maximum inhibition of DNA synthesis-augmentation by vincristine (VCR). Proceedings of the American Association for Cancer Research, 14, 50.

Gottlieb, J. A. (1974) Combination chemotherapy for metastatic sarcoma. Cancer, Chemotherapy Reports, 58, 265-270.

Hustu, H. O., Holton, C., James, D. Jun., and Pinkel, D. (1968) Treatment of Ewing's sarcoma with concurrent radiotherapy and chemotherapy. Journal of Pediatrics, 73, 249-251.

Hustu, H. O., Pinkel, D., and Pratt, C. B. (1972) Treatment of clinically localized Ewing's sarcoma with radiotherapy and combination chemotherapy. Cancer, 30, 1522-1527.

Jaffe, H. L. (1958) Ewing's sarcoma. In Tumors and Tumorous Condition of the Bones and Joints, p. 350. Philadelphia: Lee and Febiger. 
Jaffe, N., Traggis, D., Salian, S., and Cassady, J. R. (1976) Improved outlook for Ewing's sarcoma combination chemotherapy (vincristine. actinomycin D and cyclophosphamide) and radiation therapy. Cancer, 38, 1925-1930.

Jayalakshmamma, B., and Pinkel, D. (1976) Urinary-bladder toxicity following pelvic irradiation and simultaneous cyclophosphamide therapy. Cancer, 38, 701-707.

Jenkin, R. D. T., Rider, W. D., and Sonley, M. J. (1970) Ewing's sarcoma. A trial of adjuvant total-body irradiation. Radiology, 96, $151-155$.

Larson, S.-E., Boquist, L., and Bergdahl, L. (1973) Ewing's sarcoma. A consecutive series of 64 cases diagnosed in Sweden 1958-1967. Clinical Orthopaedics and Related Research, 95, 263-272.

Lichtenstein, L. (1973) Tumori delle ossa, p. 345 Rome: Verducci.

Macintosh, D. J., Price, C. H. G., and Jeffree, G. M. (1975) Ewing's tumour. A study of behaviour and treatment in forty-seven cases. Journal of Bone and Joint Surgery, 57.B, 331-340.

Marsa, G. W., and Johnson, R. E. (1971) Altered pattern of metastasis following treatment of Ewing's sarcoma with radiotherapy and adjuvant chemotherapy. Cancer, 27, 1051-1054.

Marsden, H. B., and Steward, J. K. (1968) Tumours in children. Recent Results in Cancer Research 13. Heidelberg, New York: Springer-Verlag

Mathé, G., Schneider, M., and Schwarzenberg, L. (1970) The time factor in cancer chemotherapy. European Journal of Cancer, 6, 23-31.

Mathé, G., and Kernis, Y. (1975) La Chimiotherapie des Cancers, p.153 Paris: Expansion scientifique.

Mehta, Y., and Hendrickson, F. R. (1974) CNS involvement in Ewing's sarcoma. Cancer, 33, 859-862.

O'Bryan, R. M., Luce, J. K., Talley, R. W., Gottlieb, J. A., Baker, L. H., and Bonadonna, G. (1973) Phase Il evaluation of adriamycin in human neoplasia. Cancer, 32, 1-8.

Oldham, R. K., and Pomeroy, T. C. (1972) Treatment of Ewing's sarcoma with adriamycin (NSC-123127). Cancer, Chemotherapy Reports, 56, $635-639$.

Phillips, R. F., and Higinbotham, N. L. (1967) The curability of Ewing's endothelioma of bone in children. Journal of Pediatrics, $70,391-397$.

Phillips, T. L., and Sheline, G. E. (1969) Radiation therapy of malignant bone tumours. Radiology, 92, 1537-1545.

Pomeroy, T. C., and Johnson, R. E. (1975) Combined modality therapy of Ewing's sarcoma. Cancer, 35, 36-47.

Pouillart, P., Schwarzenberg, L., Mathé, G., Schneider, M., Jasmin, C., Hayat, M., Weiner, R., De Vassal, F., Amiel, J. L., Beyer, H. P., and Fajbisowicz, S. (1972) Essai clinique de combinaisons chimiothérapiques basées sur la notion de tentative de synchronisation cellulaire. Administration première d'un antimitotique suivie de l'application de produit(s) cycle ou phase dépendant(s). Nouvelle Presse Médicale, 1 , $1757-1762$.

Pouillart, R., Huong Thy Tuong, T., Brugerie, E., and L'Heritier, J. (1974) Administration séquentielle de drogues anticancéreuses: potentialisation pharmacodynamique. Biomedicine Express, 21, 471-479.

Pratt, C. B. (1972) Management of malignant solid tumours in children. Pediatric Clinics of North America, 19, $1141-1155$.

Pritchard, D. J. (1978) Personal communication.

Rosen, G., Wollner, N., Tan, C., Wu, S. J., Hajdu, S. I., Cham, W., D'Angio, G. J., and Murphy, M. L. (1974) Disease-free survival in children with Ewing's sarcoma treated with radiation therapy and adjuvant four-drug sequential chemotherapy. Cancer, 33, $384-393$.

Samuels, M. L., and Howe, C. D. (1967) Cyclophosphamide in the management of Ewing's sarcoma. Cancer, 20, 961-966.

Schabel, F. M. Jun., (1975) Concepts for systemic treatment of micrometastases. Cancer, 35, 15-24.

Schajowicz, F. (1973) Differential diagnosis of Ewing's sarcoma. In Bone-Certain Aspects of Neoplasia, pp 189-202. Edited by C. H. G. Price and F. G. M. Ross. London: Butterworths.

Sinks, L. F., and Shan, N. K. (1975) Adjunctive chemotherapy in Ewing's tumor. Are controlled studies still essential? In Conflicts in Childhood Cancer. An Evaluation of Current Management, Vol. 4, pp. 279-282. New York: Alan R. Liss. Inc.

Suit, H. D., Fernandez, C., Sutow, W., Samuels, M., and Wilbur, J. (1973) Radiation therapy and multi-drug chemotherapy in management of patients with Ewing's sarcoma. In Bone-Certain Aspects of Neoplasia, pp. 219-227. Edited by C. H. G. Price and F. G. M. Ross. London: Butterworths.

Sutow, W. W., and Sullivan, M. P. (1962) Cyclophosphamide therapy in children with Ewing's sarcoma. Cancer, Chemotherapy Reports, 23, $55-60$.

Sutow, W. W. (1968) Vincristine (NSC-67574) therapy for malignant solid tumors in children (except Wilms' tumor). Cancer. ('hemotherapy Reports, 52, 485-487.

Sutow, W. W., Vieth, T. J., Kernbach, D. J., Lane, D. M., Donaldson, M. H., and Lonsdale, D. (1971) Evaluation of chemotherapy in children with metastatic Ewing's sarcoma and osteogenic sarcoma. Cancer, Chemotherapy Reports, 55, 67-78.

Tem, M., Lattin, P. B., Jereb, B., Cham, W., Ghavimi, F., Rosen, G., Exelby, P., Marcove, R., Murphy, M. L., and D'Angio, G. J. (1976) Acute and late effects on normal tissues following combined chemo- and radiotherapy for childhood rhabdomyosarcoma and Ewing's sarcoma. Cancer. 37, 1201-1213. 